\title{
Enhancing the recovery of tiger nut (Cyperus esculentus) oil by mechanical pressing: moisture content, particle size, high pressure and enzymatic pre- treatment effects
}

Article

Accepted Version

Ezeh, O., Gordon, M. and Niranjan, K. (2015) Enhancing the recovery of tiger nut (Cyperus esculentus) oil by mechanical pressing: moisture content, particle size, high pressure and enzymatic pre-treatment effects. Food Chemistry, 194. pp. 354-361. ISSN 0308-8146 doi:

https://doi.org/10.1016/j.foodchem.2015.07.151 Available at https://centaur.reading.ac.uk/41016/

It is advisable to refer to the publisher's version if you intend to cite from the work. See Guidance on citing.

To link to this article DOI: http://dx.doi.org/10.1016/j.foodchem.2015.07.151

Publisher: Elsevier

All outputs in CentAUR are protected by Intellectual Property Rights law, including copyright law. Copyright and IPR is retained by the creators or other copyright holders. Terms and conditions for use of this material are defined in the End User Agreement. 


\section{www.reading.ac.uk/centaur}

\section{CentAUR}

Central Archive at the University of Reading

Reading's research outputs online 
Enhancing the recovery of tiger nut (Cyperus esculentus) oil by mechanical pressing:

2 moisture content, particle size, high pressure and enzymatic pre-treatment effects

3

4

5

6

7

8

9

10

11

12

13

14

15
Onyinye Ezeh*, Michael H Gordon and Keshavan Niranjan

Department of Food and Nutritional Sciences, University of Reading, Whiteknights, PO Box 226, Reading, RG6 6AP, United Kingdom.

o.a.ezeh@pgr.reading.ac.uk, +447508851467

Abbreviated running title

High Pressure and Enzyme Pre-treatment on Tiger nut Oil Recovery by Pressing 
34 ABSTRACT: Tiger nut (Cyperus esculentus) tuber contains oil that is high in 35 monounsaturated fatty acids, and this oil makes up about $23 \%$ of the tuber. The study aimed

36 at evaluating the impact of several factors and enzymatic pre-treatment on the recovery of 37 pressed tiger nut oil. Smaller particles were more favourable for pressing. High pressure pre38 treatment did not increase oil recovery but enzymatic treatment did. The highest yield 39 obtained by enzymatic treatment prior to mechanical extraction was $33 \%$ on a dry defatted basis, which represents a recovery of $90 \%$ of the oil. Tiger nut oil consists mainly of oleic acid; its acid and peroxide values reflect the high stability of the oil.

42

43 Keywords: Tiger nut oil, pressing, particle size, enzymes, polyphenol

44

45

46

47

48

49

50

51

52

53

54

55

56

57

58 


\section{INTRODUCTION}

60

61

62

Tiger nut or yellow nutsedge (Cyperus esculentus) is a perennial herb from rhizomes with hard tubers at its endings. Its use dates back to ancient Egypt (Yeboah, Mitei, Ngila, Wessjohann, \& Schmidt, 2012), while today they are cultivated in Africa, Spain, and North America. Tiger nuts are often consumed raw, roasted or ground to make beverages. There are various applications of the plant which includes the use of its extract in the cosmetic industry and production of gluten free flour.

The oil fraction of tiger nut tuber is comparable to olive oil in its fatty acid profile and is dominated mostly with oleic acid (Linssen, Kielman, Cozijnsen, \& Pilnik, 1988). It is considered to be a superior edible oil due to its stability and nutritional quality. Tiger nut oil (TNO) contains a high proportion of unsaturated fatty acids, vitamin $\mathrm{E}$ and phenolic compounds. Its phytosterol content, especially stigmasterol and campesterol, is higher than that of olive oil, which allows the two oils to be differentiated (Sánchez-Zapata, FernándezLópez, \& Angel Pérez-Alvarez, 2012). Other properties of TNO have also been investigated such as its potential for biodiesel (Ali Rehab \& El Anany, 2012).

Currently, tiger nut oil is extracted and sold as cold pressed oil. For research purposes, TNO is extracted either using a laboratory press or solvent extraction with n-hexane (Ali Rehab \& El Anany, 2012; Yeboah, Mitei, Ngila, Wessjohann, \& Schmidt, 2012). Despite the higher recovery of oil achieved with solvent extraction (over 95\%) as reported by Rosenthal and Niranjan (1996), there remains apprehensions regarding sustainable availability of petroleum based solvents, as well as the contribution of these solvents to the emission of volatile organic compounds. To overcome this problem, other methods of oil extraction have been investigated and re-visited along with pre-treatment effects on the yield of the extracted oil. Examples include employing enzymes and applying high hydrostatic pressure treatment. Enzymes are used to degrade cellular wall components such as cellulose, and pectin and this 
facilitates oil release from the cells. They are commonly used in aqueous extraction processes where they have been found to significantly increase oil recoveries from oil seeds. Peanuts, soybeans, pumpkin, and horse radish seeds are some materials that have benefitted from the use of enzymes in aqueous extraction (Mat Yusoff, Gordon, \& Niranjan, 2015). Only a few studies have implemented use of enzymes prior to mechanical oil extraction despite the potential benefits it may offer. With mechanical presses, there is no difficulty of deemulsification that arises with aqueous extraction and this eliminates an additional processing step.

Mechanical separation of oil from oil seeds can be done either using expellers (screw press) or hydraulic presses. The high quality oil obtained is one of the reasons why these are continually being used especially as there is an increasing niche market for novel oils. In some rural areas, it also remains the sole method of oil extraction. But it still is an inefficient process. Depending on the equipment used, authors have conducted studies to increase oil recoveries and optimize the process by varying operational variables like temperature, applied pressure and time (Adeeko \& Ajibola, 1990; Ajibola, Eniyemo, Fasina, \& Adeeko, 1990). Sample preparation must also be taken into account, as pre-treatments such as the application of extrusion, and enzymes are employed (Nelson, Wijeratne, Yeh, Wei, \& Wei, 1987; Smith, Agrawal, Sarkar, \& Singh, 1993). Generally these treatment lead to increases in oil yields because they tend to either soften and/or destroy cellular structure thus aiding the extraction. When hydraulic presses are used, important parameters that have been observed to influence oil yields are moisture content of sample, temperature, maximum applied pressure, and particle size.

Extraction of oil from tiger nut has not been researched extensively and has very few reported studies. A majority of growers of the tuber reside in African countries and they stand to benefit from more research in this area especially with the multiple uses of the oil. 
109 Potentially, it could substitute for the more expensive imported olive oil in these countries. In 110 addition, the oil could be employed to improve the diets of consumers in penurious areas.

111 Consumption of a blend of coconut and tiger nut oil for instance has been shown to control

112 the total plasma cholesterol levels in albino rats and also reduce their LDL- cholesterol levels

113 (Ali Rehab \& El Anany, 2012).

114 There is a paucity of research reports on techniques for extraction of tiger nut oil or 115 optimising the yield of oil. However a study of the effects of extraction parameters on oil 116 yield when using supercritical $\mathrm{CO}_{2}$ was recently reported (Lasekan \& Abdulkarim, 2012).

117 There are also a few studies on enzymatic aqueous oil extraction. In terms of pre-treatments, 118 high pressure is not commonly used prior to oil extraction. It is commercially used in 119 pasteurization and food preservation as the high pressures applied inactivate microbes, spores, and spoilage inducing enzymes (Ly-Nguyen, Van Loey, Smout, ErenÖzcan, Fachin, Verlent, et al., 2003). It has though been used along with enzymatic aqueous extraction of soybean flakes (Uhm \& Yoon, 2011). This study aims to investigate the impact of moisture content in the tubers, particle size, high hydrostatic pressure and enzymatic pre-treatment prior to oil extraction by mechanical pressing on the recovery of tiger nut oil. Oil quality parameters are reported for the pressed oil (without enzymatic treatment). 


\section{MATERIALS AND METHODS}

135

136

137

138

139

140

141

142

143

144

145

146

147

148

149

150

151

152

153

154

155

156

\subsection{Samples}

Dried brown tiger nuts from Spain, purchased from Real Foods, Edinburgh UK were used for all experiments.

\subsection{Chemicals}

Fatty acid methyl ester standards, $\alpha$-tocopherol standard, gallic acid, methanol, alcohol oxidase (from Pichia pastoris), purpald (4-amino-3-hydrazino-5-mercapto-1, 2, 4-triazole), phosphate buffer, safranin and sodium hydroxide were purchased from Sigma-Aldrich (Dorset, UK). All chemicals were of analytical grade.

\subsection{Sample preparation and treatments}

The initial moisture content of tiger nuts was measured using an infrared moisture analyser (Sartorius, Surrey UK) and this was given on a wet basis (wb). They were then soaked in distilled water at room temperature for $6 \mathrm{~h}$, followed by drying in a conventional oven at 70 ${ }^{\circ} \mathrm{C}$ for $13 \mathrm{~h}$. A preliminary study was carried out to obtain a drying curve and used to determine the time taken to achieve an initial moisture content of $4 \%$ (wb) for all samples. The samples with the desired moisture content were prepared by adding calculated amounts of distilled water using equation 1 (Mwithiga \& Sifuna, 2006) and mixed thoroughly. The weighed tubers were placed in polyethylene bags and kept in a refrigerator for a minimum of $48 \mathrm{~h}$ to establish uniform moisture content. Prior to oil extraction, they were withdrawn and left for $2 \mathrm{~h}$ at room temperature to equilibrate.

$$
Q=\frac{w_{i}\left(m_{f}-m_{i}\right)}{\left(100-m_{f}\right)}
$$

(Equation 1)

where $\mathrm{Q}=$ mass of water to be added in grams, $\mathrm{w}_{\mathrm{i}}$ is the initial mass of the sample in grams, $\mathrm{m}_{\mathrm{i}}$ and $\mathrm{m}_{\mathrm{f}}$ are the initial and desired final moisture contents in percentages $(\mathrm{wb})$, respectively. 
157 The prepared samples prior to pressing were ground in a coffee mill and sieved with three 158 ASTM testing meshes to produce average particle sizes of $\leq 1.16 \mathrm{~mm}, \leq 0.841 \mathrm{~mm}$ and $\leq 0.5$ $159 \mathrm{~mm}$.

\subsubsection{High Pressure Processing}

161 Tiger nuts were dried for $1.5 \mathrm{~h}$ or until the moisture content was between $6.5-8 \%$. They were then ground, and sieved to a particle size of $\leq 0.85 \mathrm{~mm}$. $30 \mathrm{~g}$ of the samples were vacuum sealed in polyethylene bags and placed in a pressure vessel (Stanstead Fluid Power, Ltd) to be subjected to pressures of 50, 300, 500 and $700 \mathrm{MPa}$ (15 min holding time, $40{ }^{\circ} \mathrm{C}$ ). Whole tubers in $0.5 \mathrm{M}$ citric acid were also high pressure treated. A preliminary study found no interaction between pressure, temperature and time on the yield. A mixture of water and 1, 2propanediol $(70: 30, \mathrm{v} / \mathrm{v})$ served as the pressure transmitting fluid. The adiabatic temperature rise during the pressure treatment was $3.3{ }^{\circ} \mathrm{C}$ per $100 \mathrm{MPa}$.

\subsubsection{Enzymatic treatment}

Protease (from Bacillus licheniformis), $\alpha$-amylase (Bacillus licheniformis) and Viscozyme L (hemi cellulolytic enzyme mixture from Aspergillus) were purchased from Sigma-Aldrich, UK. A combination of all three enzymes was used (1:1:1). Enzymes and their hydrolysis conditions were based on specifications given by suppliers and experiments done in our laboratory. Whole tiger nut tubers were soaked in distilled water for $6 \mathrm{~h}$, ground and sieved to a particle size of $\leq 0.425 \mathrm{~mm}$. Enzymes of varying total weights $(0.15 \mathrm{~g}, 0.30 \mathrm{~g}, 0.45 \mathrm{~g})$ were added to $50 \mathrm{ml}$ of distilled water, $30 \mathrm{~g}$ of ground tiger nut sample, and $\mathrm{pH}$ was adjusted to 8 using $0.5 \mathrm{M} \mathrm{NaOH}$. Incubation was carried out for $6 \mathrm{~h}$ at $40{ }^{\circ} \mathrm{C}$ in a water bath with a linear agitation speed of 180 strokes per min. After incubation, the mixture was dried in a vacuum oven till the moisture content was between $6.5-8 \%$. Temperature in the oven was $55{ }^{\circ} \mathrm{C}$ while the maximum pressure reached was $700 \mathrm{~mm} \mathrm{Hg}$. Following drying, oil was extracted by pressing. 


\subsection{Mechanical Pressing of Tiger nut oil}

183

184

185

Tiger nut oil was obtained by double pressing $30 \mathrm{~g}$ of ground tiger nuts with a hydraulic laboratory press (Specac, Ltd UK). A maximum pressure of $38 \mathrm{MPa}$ was exerted due to the limitation of the strength of the nylon sieve material used. The samples were placed in the sieve and then in a metal chamber. The total time for pressing was between 40-50 s. Hexane was used to collect the expressed oil and recovered in a rotary evaporator. The amount of oil extracted was measured gravimetrically and stored in an amber glass bottle for analysis.

Hexane extraction was carried out to determine the total extractable oil in tiger nuts and to measure total oil recovery. The total oil content was measured gravimetrically from $10 \mathrm{~g}$ of ground tiger nuts extracted with $150 \mathrm{ml}$ hexane for $6 \mathrm{~h}$ in a Soxhlet unit. Hexane was recovered in a rotary evaporator. Residual solvent was removed in an oven at $105{ }^{\circ} \mathrm{C}$ for 15 min and the residue was cooled in a desiccator. Throughout the work, oil recovery is synonymous with oil yield.

Pressing after enzymatic treatment was carried out in $30 \mathrm{~min}$. Controls consisted of pressing for 30 min without enzymatic pre-treatment.

\subsection{Cell evaluation}

\subsubsection{Methanol content in tissues}

A spectrophotometric method was used to determine methanol content (Gonzalez, Jernstedt, Slaughter, \& Barrett, 2010). Pectin methyl esterase activity was assayed by determination of the amount of methanol present in the tissues. Methanol is enzymatically oxidized to formaldehyde with alcohol oxidase and calorimetrically determined with Purpald (4- amino3-hydrazinio-5-mercapto-1,2, 4 triazole). Ground tiger nut sample (1g) was vortexed with 50 $\%$ trichloracetic acid (TCA) and distilled water in the ratio 1:2:1. The mixture was centrifuged and the oxidation was begun by adding $0.25 \mathrm{ml}$ of the vortexed mixture to $0.9 \mathrm{ml}$ of $100 \mathrm{mM}$ phosphate buffer ( $\mathrm{pH} 7.5), 0.75 \mathrm{ml}$ supernatant, $0.5 \mathrm{ml}$ distilled water, and $1 \mathrm{ul}$ 
alcohol oxidase $(27 \mathrm{U} / \mathrm{mg}$ protein, $42 \mathrm{mg}$ protein $/ \mathrm{ml})$. The samples were incubated in a water bath at $30{ }^{\circ} \mathrm{C}$ for $10 \mathrm{~min}$ after which $2 \mathrm{ml}$ of $5 \mathrm{mg} / \mathrm{ml}$ Purpald in $0.5 \mathrm{M} \mathrm{NaOH}$ was added and the mixture was left for an additional $30 \mathrm{~min}$. At the end of this period, $6 \mathrm{ml}$ of distilled water was added and the absorbance at $550 \mathrm{~nm}$ was measured.

\subsubsection{Confocal Light Scanning Microscopy}

The staining method reported by Sineiro, Domínguez, Núñez and Lema (1998) was adopted and modified. Ground tiger nut samples were mounted on glass slides using Evo-Stik rapid set adhesive. Cell walls were stained in Safranin solution for $1 \mathrm{~min}(10 \mathrm{~g}$ safranin in $155 \mathrm{ml}$ $95 \%$ ethanol and $145 \mathrm{ml}$ distilled water; this was diluted 1:1 with $50 \%$ ethanol). Sections were rinsed afterwards with distilled water and observed under a Leica SP2 Inverted Confocal Microscope (Carl Zeiss) operating in confocal mode. A Leica 10x/0.3 HC PL Fluotar dry lens (Carl Zeiss) was used. An Argon laser $(488 \mathrm{~nm}, 496 \mathrm{~nm}$ and $514 \mathrm{~nm}$ excitation) provided the incident light and emission bandwidth set from 525 to $606 \mathrm{~nm}$. The obtained images were $1024 \times 1024$ pixels in size and were scanned at various zoom factors to obtained desired magnifications.

\subsection{Oil Analysis}

Non-treated pressed oil was used in all oil analysis.

\subsubsection{Fatty Acid Content}

The pressed oil was analysed for fatty acid composition by Gas Chromatography (Agilent HP 6890 fitted with FID). Fatty acid methyl esters were prepared by saponification as described in the International Union of Pure and Applied Chemistry method 2.301 (Dieffenbacher \& Pocklington, 1992). The esters were analysed using fused silica capillary column Varian CPSil $88(50 \mathrm{~m} \times 0.25 \mathrm{~mm} \times 0.20 \mu \mathrm{m})$. The injector temperature was $250{ }^{\circ} \mathrm{C}$; detection temperature was $260{ }^{\circ} \mathrm{C}$ and oven temperature was initially $100{ }^{\circ} \mathrm{C}$, held for $3 \mathrm{~min}$ and 
ramped to $240{ }^{\circ} \mathrm{C}$ at $4{ }^{\circ} \mathrm{C}$ per min. The carrier gas was hydrogen at a flow rate of $0.8 \mathrm{ml} / \mathrm{min}$.

The fatty acids were identified by comparing retention times with those of standards.

\subsubsection{Acid and Peroxide Values}

Acid value (AV) and peroxide values were determined according to $\mathrm{Cd} 3 \mathrm{~d}-63$ and $\mathrm{Cd} 8 \mathrm{~b}-90$ AOCS official methods respectively (Firestone, 1998).

\subsubsection{Tocopherol Content}

For tocopherol extraction and analysis, the procedure described by Costa, Ballus, TeixeiraFilho and Godoy (2010) was followed. Analysis was performed with a HPLC-UV system (Agilent 1200, Manchester, UK) using a Nucleosil C-18-100 reverse phase column $(25 \mathrm{~cm} \times$ $4.6 \mathrm{~mm}$ i.d.) with a particle size of $5 \mu \mathrm{m}$ (Macherey-Nagel, Duren, Germany). Dilute concentrations of $\alpha$-tocopherol standard were prepared by dissolving in methanol. Tocopherol was identified by comparing the retention times with those of the standards and comparing the absorption spectra obtained by the DAD. An external calibration was used for quantification.

\subsubsection{Total Phenolic Compound Analysis}

The extraction of phenols was carried out using liquid-liquid extraction with methanol as solvent. The procedure reported by Baiano, Gambacorta, Terracone, Previtali, Lamacchia, and La Notte (2009) was followed. $2 \mathrm{ml}$ of methanol/water (70:30, v/v) and $2 \mathrm{ml}$ of hexane were added to $5 \mathrm{~g}$ of tiger nut oil and vortexed for $10 \mathrm{~min}$. The organic phase and the aqueous phase were separated by centrifugation $\left(6000 \mathrm{rpm}, 4{ }^{\circ} \mathrm{C}, 10 \mathrm{~min}\right)$. The aqueous phase containing the phenolics was collected and centrifugation was repeated (13000 rpm, room temperature, $4 \mathrm{~min}$ ). Finally, the aqueous phase was collected with a pipette for analysis. Total phenolic content was quantified using a spectrophotometric method (Stanković, 2011). The hydroalcoholic extract or blank methanol sample $(0.5 \mathrm{ml})$ was mixed with $10 \%$ FolinCiocalteu reagent $(2.5 \mathrm{ml})$ dissolved in water and $7.5 \% \mathrm{Na}_{2} \mathrm{CO}_{3}(2.5 \mathrm{ml})$. The mixtures were 
incubated at $45^{\circ} \mathrm{C}$ for $45 \mathrm{~min}$ and the absorbance was measured using a spectrophotometer at

$257765 \mathrm{~nm}$. A standard curve was prepared using standard diluted solutions of gallic acid in methanol. Total phenolic content is expressed as milligrams of gallic acid equivalents (GAE)

259 per kg of oil.

\subsection{Statistical Analysis}

261 All analysis was done in triplicate and the mean values are presented. Statistical analysis was carried out by ANOVA using SPSS Version 20 Statistical software (SPSS Inc, Chicago, USA). Significance was defined at $\mathrm{p}<0.05$.

\section{RESULTS AND DISCUSSION}

\subsection{Effects of Moisture Content and Particle Size}

The total extractable oil in the tiger nut tuber was $23.1 \%(\mathrm{w} / \mathrm{w})$ or $35.5 \%$ on a dry defatted basis (d.d.b) taking into account the initial moisture content of the samples. Thus it is a low oil bearing material, similar to soybean (18-20\%) (Nelson, Wijeratne, Yeh, Wei, \& Wei, 1987). The lipid content falls within the range of 22.8-32.8 \% reported in literature (Sánchez-

Zapata, Fernández-López, \& Angel Pérez-Alvarez, 2012) .

Reducing the particle size was necessary to increase the oil recovery (Figure 1). These results were in agreement with those obtained for ground melon seeds (Ajibola, Eniyemo, Fasina, \& Adeeko, 1990) and in contrast to results obtained for peanuts. Finely ground melon seed particles $(1.10 \mathrm{~mm})$ were found to give higher oil yields compared to coarsely ground particles $(1.85 \mathrm{~mm})$. In contrast, peanut oil yield was increased when the particle size was increased (Adeeko \& Ajibola, 1990). Particle size is known to play a role in oil extraction processes such as solvent and aqueous extraction (A Rosenthal, Pyle, \& Niranjan, 1998). In these techniques the smaller the particle size, the higher the oil recovery because of an increase in surface area allowing for more contact between the solvents and the oleaginous 
material. The pressing operation has been described as being analogous to a capillary

282 filtration process, and the Hagen-Poiseuille equation below expresses this (Sorin-Stefan, Ionescu, Voicu, Ungureanu, \& Vladut, 2013)

$$
V(m 3)=\frac{\pi \cdot p \cdot d \cdot t}{128 . \eta \cdot l} \quad(\text { Equation } 2)
$$

Where $\mathrm{V}\left(\mathrm{m}^{3}\right)$ - volume of separated liquid (passing through capillaries); $\mathrm{p}\left(\mathrm{N} / \mathrm{m}^{2}\right)$ - apparent pressure; $d(m)$ - diameter of capillary channel; $\eta(\mathrm{Pa} \mathrm{s})$ - dynamic viscosity of liquid; 1 (m) length of capillary channel; $\mathrm{t}(\mathrm{s})$ - time of applied pressure.

From equation 2, the volume of oil that gets released is proportional to the pore diameter and inversely proportional to the length of the capillary channel. The pore diameter and capillary channel length can be increased and decreased respectively with greater cellular destruction. This may explain the higher yields obtained with smaller particles.

Despite the fact that moisture content is a key controlling factor in mechanical oil extraction, oil yield was not significantly affected by moisture content of the samples. However, the maximum oil yields (17-18\%, d.d.b) for each particle size used, were observed to occur between 6.8-8\% moisture. Different oilseeds exhibit different behaviour with varying moisture levels. It was reported for walnuts and peanuts, that an increase in moisture content from $2.4 \%$ to $7 \%$ increased oil extraction yield from $61 \%$ to $84 \%$ while in some materials like sesame, optimum moisture content exists. Although these extraction processes were carried out in a continuous process, similar observations were noted for hydraulic presses (Savoire, Lanoisellé, \& Vorobiev, 2013). In the case of tiger nuts, even though the impact of moisture level on extraction yield was found to be statistically insignificant, subsequent pressing experiments were carried within the observed favourable moisture level range. Other factors that influence oil yield include temperature and pressure. In this study, existing constraints prevented a manipulation of these factors; pressure due to the strength of the 
sieving material used and temperature due to the lack of temperature control of the hydraulic press.

\subsection{Effect of High Pressure Processing}

308 Samples pre-treated with high pressure showed no significant increase in oil recovery regardless of the pressure employed (Figure 2). The high pressures (50-700 MPa) did not cause any further destruction of the parenchyma cells which had already suffered some disintegration due to the grinding process. Confocal images of control and high pressure treated samples (300-700 MPa) revealed similar cellular damage in all samples (Figure 3), thus supporting the hypothesis that HPP does not induce any damage to cell walls. Safranin was used to stain cell walls and is also known to stain lipids which explain the multiple drops in the images. Focusing on different regions of the cells showed areas with intact cell walls and some cell damage. Two microscope slides per treated sample were viewed under the confocal laser microscope.

According to Jung, Maurer \& Johnson, (2009), application of high pressures (200 MPa and $500 \mathrm{MPa}$ ) did not result in any significant increase in oil yield following both aqueous and enzyme assisted aqueous extraction. It was suggested that high pressure treatment did not promote any cell rupture in cotyledon cells of sunflower seeds. This observation can also be used to explain the lack of an effect on tiger nut tubers. Tiger nut tubers have a tough texture, even tougher than potatoes and this characteristic was attributed to the cross linking of diferulic acid with arabinoxylans in the parenchyma cells of the tubers (Parker, $\mathrm{Ng}, \mathrm{Smith}, \&$ Waldron, 2000). High pressure alone is not sufficient to induce cell separation as it is only able to break weak non covalent bonds (Jung, Maurer, \& Johnson, 2009). An initial hypothesis that the lack of effect of HPP on the oil yield was due to pectin methyl esterase (PME) activity often present in plant cells was considered. PME demethylates pectin molecules, releasing pectin with free carboxyl groups and methanol. Pectin precipitates in the 
presence of calcium forming strong bond linkages that preserves plant tissues when HPP is applied. Studies have shown HPP as an alternative to thermal treatment to maintain membrane integrity of tissues (De Roeck, Sila, Duvetter, Van Loey, \& Hendrickx, 2008; Gonzalez, Jernstedt, Slaughter, \& Barrett, 2010). If this was the case, the addition of an acid may be able to combat the effects of PME, and this was investigated.

\subsection{Effect of Citric Acid and Methanol Content in Cell tissues}

The tubers were placed in $0.5 \mathrm{M}$ citric acid during the application of high pressure (700

MPa). Citric acid was used to inhibit pectin-calcium linkages that may have formed if PME activity was present in tiger nut tissues. An increase in plant cells hardness or toughening when calcium is present has been attributed to the precipitation of pectin. Despite the addition of citric acid, tiger nut oil recovery did not increase. This suggests that pectin-calcium linkages are not responsible for the lack of cell destruction by HPP.

Parker, Ng, Smith \& Waldron, (2000) attributed the toughness of cell walls of tiger nut tuber to phenolic acids, particularly diferulic acid. The toughness was recognised to be greater than that of both raw potatoes and Chinese water chestnut. These acids were suspected to form stable bonds between polysaccharides in the cell wall. It was also recommended that cell separation in tiger nut tubers may be achieved by using hot dilute acid $\left(100{ }^{\circ} \mathrm{C}\right)$. High temperature was avoided because it would cause starch present to gelatinize and also affect oil quality.

The methanol content was investigated by a colorimetric method. An increase in absorbance indicates an increase in amount of methanol released. This would suggest an increase in PME activity. From Figure 4, there were no significant differences between control and all high pressure treated samples except $700 \mathrm{MPa}$. The absorbance value of the $700 \mathrm{MPa}$ treated sample was observed to be lower. The action of grinding already plays a role in some cellular destruction, which may have led to PME release from within the cells and hence the observed 
measured absorbance in control and pressure treated samples. The reduced absorbance suggests a decrease in PME activity due to the high pressure. Enzymes tend to be resilient at high pressures and PME is no exception. In carrots, PME was observed to have high stabilities even at high pressures up to $825 \mathrm{MPa}$ (Ly-Nguyen, et al., 2003). In another study, a high temperature, high pressure process was not able to solubilize cell walls but a low pressure/high temperature combination did achieve this $\left(0.1 \mathrm{MPa}, 80{ }^{\circ} \mathrm{C}\right)$ (De Roeck, Sila, Duvetter, Van Loey, \& Hendrickx, 2008). PME of tiger nut may require thermal treatment for complete inactivation but this was not needed for the purpose of this study.

\subsection{Effect of Enzymatic Pre-treatment}

The degrading action of enzymes significantly increased the pressed oil recovered. Tiger nut is known to have a relatively high starch content of tiger nut of about 23 . Cellulose also makes up a large fraction of its crude fiber. The occurrence of these cell components in tiger nuts would explain why $\alpha$-amylase, protease and cellulolytic enzyme mixture enhanced oil recovery. A confocal image with Safranin stained cell walls confirmed greater cellular damage as a result of enzymatic treatment (Figure 3). An enzyme to substrate ratio of $1 \%$ was found to achieve the highest oil recovery of $90 \%$. Products from the degraded materials may prevent enzymes from reaching their substrates and any additional enzyme was not beneficial. The recovered oil was much higher than some reported recoveries obtained from other materials via pressing such as values for soybeans (64\%), or rosehip (74\%) (Concha, Soto, Chamy, \& Zúñiga, 2004; Smith, Agrawal, Sarkar, \& Singh, 1993). In other studies where higher oil recoveries up to $98 \%$ were obtained, thermal treatments as well as longer pressing times may have further improved the oil extraction. In addition, increasing pressing time from $40-50 \mathrm{~s}$ to $30 \mathrm{~min}$ contributed to an $11 \%$ increase in oil yield without any enzymatic pre-treatment. 


\subsection{Fatty Acid Composition}

The most abundant saturated fatty acids in pressed tiger nut oil are palmitic $(13.5 \%)$ and stearic acid (6.3\%) while the major unsaturated fatty acid is oleic acid (67.4\%). The fatty acid composition is given in Table 1. Traces of myristic, gondoic, linolenic, and arachidic acids were also detected. The concentration of oleic acid is in agreement with previous studies and similar to that of olive oil (Linssen, Kielman, Cozijnsen, \& Pilnik, 1988). Eteshola \& Oraedu, (1996) found a rather high proportion of myristic acid (28.1\%) with a much lower oleic acid content (44.8\%). This discrepancy in values may be due to a difference in the origin of the tiger nut tubers, genetic history, the age of the tissue analysed and temperature and oxygen tension, since these variables can alter the lipid content of oilseeds (Eteshola \& Oraedu, 1996). Aside from this minor difference, the composition of fatty acids is similar to those reported in a number of studies and similar to the fatty acid profiles of olive, hazelnut, macadamia and avocado oil (Sánchez-Zapata, Fernández-López, \& Angel Pérez-Alvarez, 2012). As fatty acid composition is a determinant of the quality of edible oils, the high concentration of monounsaturated fatty acids (MUFA) makes it desirable due to its good shelf life and potential health benefits. The carbon double bonds in fatty acids are prone to oxidation, producing aldehydes, ketones and hydrocarbons that cause odours and flavours linked with rancidity. Hence, oxidative stability increases with decreased levels of unsaturated fatty acids, most especially PUFA (Moore \& Knauft, 1989). This has been observed for olive oil and the lower PUFA content in tiger nut oil gives it the same advantage. MUFAs are much more stable and less prone to peroxidation due to their chemical structure compared to PUFAs. The above mentioned health benefits of olive oil are at least partly due to the MUFA content. Tiger nut oil can be substituted for olive oil in areas where the tuber is grown locally. 


\subsection{Quality Indices}

406

407

408

409

410

411

412

413

414

415

416

417

418

419

420

421

422

423

424

425

426

427

428

429

The acid and peroxide values were found to be $1.2 \mathrm{mg} \mathrm{KOH} / \mathrm{g}$ oil and $2.1 \mathrm{mEq} / \mathrm{kg}$ oil respectively. Acid value quantifies the concentration of free fatty acids and is an important indicator of oil quality. The low acid value obtained indicates the low level of free fatty acid in pressed tiger nut oil and thus reflects its high quality. Ali Rehab \& El Anany, (2012) reported an even lower acid value of 0.31 in pressed tiger nut oil. Free fatty acids in oil occur as a result of hydrolysis which requires moisture to develop but the non-enzymic reaction only occurs at high temperatures. Lipase in the tubers may have increased the hydrolysis reaction leading to the release of free fatty acid during grinding and extraction.

The peroxide value of tiger nut oil is lower than the value determined by Yeboah, Mitei, Ngila, Wessjohann and Schmidt (2012) of $5.54 \mathrm{mEq} / \mathrm{kg}$ which was deemed reasonable as it was in accordance with Codex recommended values for virgin olive oil. Peroxide value measures the concentration of hydroperoxides, which are the intermediate products during oxidation in oil and so is used to detect the early stages of rancidity. It gives an indication of the development of oxidative rancidity in oils. The low value of $2.1 \mathrm{mEq} / \mathrm{kg}$ found in this study shows that oxidation had not progressed to a significant extent in this sample of tiger nut oil.

\subsection{Total Phenolic Content}

Tiger nut oil polyphenol content was $17.9 \mathrm{mg}$ GAE per $\mathrm{kg}$ oil. This is lower than the value found by Ali Rehab and El Anany (2012) who obtained their nuts from Egypt which might explain the differences. Pellegrini, Visioli, Buratti and Brighenti (2001) reported on the polyphenol content in refined, virgin and extra virgin oils as $0.4,1.4-2.4$ and 7.3-26.5 mg GAE/ $100 \mathrm{~g}$ oil respectively. Soybean, sunflower and corn oils have been found to contain 68, 0.3-0.4 and less than $0.1 \mathrm{mg} / 100 \mathrm{~g}$ oil respectively (Valavanidis, Nisiotou, Papageorgiou, Kremli, Satravelas, Zinieris, et al., 2004). Compared with these values, tiger nut oil has 
similar polyphenol content to virgin olive oil and much lower than soybean and extra virgin olive oil. The phenolic content of oils is important in assessing its antioxidant activity. These bioactive compounds play a protective role in the degradation of tocopherols during cooking processes and storage (Marfil, Giménez, Martínez, Bouzas, Rufián - Henares, Mesías, et al., 2011). Polyphenol content and oxidative stability have been found to have a linear correlation in virgin olive oil during storage at $60{ }^{\circ} \mathrm{C}$ and polyphenol content was proposed as an indicator of olive oil quality (Gutfinger, 1981). On the basis of the high MUFA content and the moderate polyphenol content, one can expect the oxidative stability of tiger nut oil to be comparable to that of olive oil.

\subsection{Tocopherol Content}

The quantification of $\alpha$-tocopherol is given in Table 2. It shows that tiger nut oil contained $145.7 \mu \mathrm{g} / \mathrm{g}$. $\beta$-tocopherol was not quantified but was identified to be present in the oil. The total tocopherol content of tiger nut oil is thus expected to be higher than $145.7 \mu \mathrm{g} / \mathrm{g}$. Yeboah, Mitei, Ngila, Wessjohann and Schmidt (2012) reported an $\alpha$-tocopherol content of $86.7 \mu \mathrm{g} / \mathrm{g}$ in solvent extracted tiger nut oil. Tocopherol content is affected by mode of oil extraction. Organic solvents are able to penetrate the cells of the oil-containing plant material dissolving more non-polar compounds. For a crude oil, the tocopherol value obtained is higher than some olive oil values of $100-250 \mathrm{mg} / \mathrm{kg}$, but there is a high variability in the amount of tocopherols reported (Boskou, 2008). The high tocopherol content also contributes to the stability of the oil as tocopherols acts as antioxidants. $\alpha$-Tocopherol is more stable than $\beta-$ tocopherol. A good correlation between tocopherol and PUFA content has also been described, suggesting that tocopherols are important in protecting them against oxidation (Quiles, Ramírez-Tortosa, Gómez, Huertas, \& Mataix, 2002). 


\section{CONCLUSION}

457 Small particle sizes with 6.88 to $8 \%$ moisture content were found to give higher oil 458 recoveries. High pressure did not improve the extractability of oil and this may be due to the 459 presence of diferulic bonds present in the cell walls. Enzyme pre-treatment on the other hand 460 allowed for a $90 \%$ oil recovery. The triacylglycerol profile of tiger nut oil predominantly 461 consists of oleic acid and $\mathbf{7 8 . 6} \%$ of the oil is unsaturated fatty acid. It can thus be used as a 462 source of these beneficial fatty acids. The acid and peroxide values indicate its high stability 463 and these were confirmed by the high polyphenol and tocopherol content. Polyphenols and 464 tocopherols both have antioxidant capabilities, protecting oil from oxidative rancidity and 465 prolonging its shelf life. Higher temperature and pressure were proposed to further increase 466 the oil extracted from tiger nuts.

467

\section{ACKNOWLEDGEMENTS}

469 The authors thank Petroleum Technology Development Fund (PTDF) for supporting the 470 doctoral grant of one of the authors (Onyinye Ezeh).

471

472

473 


\section{REFERENCES}

Adeeko, K., \& Ajibola, O. (1990). Processing factors affecting yield and quality of mechanically expressed groundnut oil. Journal of Agricultural Engineering Research, 45, 31-43.

Ajibola, O. O., Eniyemo, S. E., Fasina, O. O., \& Adeeko, K. A. (1990). Mechanical expression of oil from melon seeds. Journal of Agricultural Engineering Research, 45(0), 45-53.

Ali Rehab, F. M., \& El Anany, A. M. (2012). Physicochemical studies on sunflower oil blended with cold pressed tiger nut oil during deep frying process. Grasas y Aceites, 63(4), 455-465.

Baiano, A., Gambacorta, G., Terracone, C., Previtali, M., Lamacchia, C., \& La Notte, E. (2009). Changes in Phenolic Content and Antioxidant Activity of Italian Extra-Virgin Olive Oils during Storage. Journal of Food Science 74(2), C177-C183.

Boskou, D. (2008). Olive Oil: Minor Constituents and Health: CRC Press.

Concha, J., Soto, C., Chamy, R., \& Zúñiga, M. E. (2004). Enzymatic pretreatment on rose-hip oil extraction: Hydrolysis and pressing conditions. Journal of the American Oil Chemists' Society, 81(6), 549-552.

Costa, P. A. d., Ballus, C. A., Teixeira-Filho, J., \& Godoy, H. T. (2010). Phytosterols and tocopherols content of pulps and nuts of Brazilian fruits. Food Research International, 43(6), 1603-1606.

De Roeck, A., Sila, D. N., Duvetter, T., Van Loey, A., \& Hendrickx, M. (2008). Effect of high pressure/high temperature processing on cell wall pectic substances in relation to firmness of carrot tissue. Food Chemistry, 107(3), 1225-1235.

Dieffenbacher, A., \& Pocklington, W. D. (1992). Standard Methods for the Analysis of Oils, Fats and Derivatives (7 ed.): Wiley.

Eteshola, E., \& Oraedu, A. C. I. (1996). Fatty acid compositions of tigernut tubers (Cyperus esculentus L.), baobab seeds (Adansonia digitata L.), and their mixture. Journal of the American Oil Chemists' Society, 73(2), 255-257.

Firestone, D. (1998). Official methods and recommended practices of the AOCS: American Oil Chemists' Society.

Gonzalez, M., Jernstedt, J., Slaughter, D., \& Barrett, D. (2010). Influence of cell integrity on textural properties of raw, high pressure, and thermally processed onions. Journal of Food Science, 75(7), E409-E416.

Gutfinger, T. (1981). Polyphenols in olive oils. Journal of the American Oil Chemists' Society, 58(11), 966-968.

Jung, S., Maurer, D., \& Johnson, L. A. (2009). Factors affecting emulsion stability and quality of oil recovered from enzyme-assisted aqueous extraction of soybeans. Bioresource Technology, 100(21), 5340-5347.

Lasekan, O., \& Abdulkarim, S. M. (2012). Extraction of oil from tiger nut (Cyperus esculentus L.) with

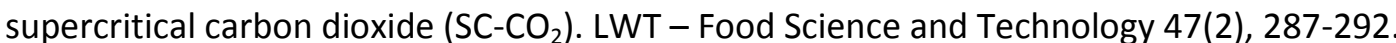

Linssen, J. P. H., Kielman, G. M., Cozijnsen, J. L., \& Pilnik, W. (1988). Comparison of chufa and olive oils. Food Chemistry, 28(4), 279-285.

Ly-Nguyen, B., Van Loey, A. M., Smout, C., ErenÖzcan, S., Fachin, D., Verlent, I., Truong, S. V., Duvetter, T., \& Hendrickx, M. E. (2003). Mild-Heat and High-Pressure Inactivation of Carrot Pectin Methylesterase: A Kinetic Study. Journal of Food Science, 68(4), 1377-1383.

Marfil, R., Giménez, R., Martínez, O., Bouzas, P. R., Rufián-Henares, J. A., Mesías, M., \& CabreraVique, C. (2011). Determination of polyphenols, tocopherols, and antioxidant capacity in virgin argan oil (Argania spinosa, Skeels). European Journal of Lipid Science and Technology, 113(7), 886-893. 
Mat Yusoff, M., Gordon, M. H., \& Niranjan, K. (2015). Aqueous enzyme assisted oil extraction from oilseeds and emulsion de-emulsifying methods: A review. Trends in Food Science \& Technology, 41(1), 60-82.

Moore, K., \& Knauft, D. (1989). The inheritance of high oleic acid in peanut. Journal of Heredity, 80(3), 252-253.

Mwithiga, G., \& Sifuna, M. M. (2006). Effect of moisture content on the physical properties of three varieties of sorghum seeds. Journal of Food Engineering, 75(4), 480-486.

Nelson, A. I., Wijeratne, W. B., Yeh, S. W., Wei, T. M., \& Wei, L. S. (1987). Dry extrusion as an aid to mechanical expelling of oil from soybeans. Journal of the American Oil Chemists' Society, 64(9), 1341-1347.

Parker, M. L., Ng, A., Smith, A. C., \& Waldron, K. W. (2000). Esterified phenolics of the cell walls of chufa (Cyperus esculentus L.) tubers and their role in texture. Journal of Agricultural and Food Chemistry 48(12), 6284-6291.

Pellegrini, N., Visioli, F., Buratti, S., \& Brighenti, F. (2001). Direct analysis of total antioxidant activity of olive oil and studies on the influence of heating. Journal of Agricultural and Food Chemistry 49(5), 2532-2538.

Quiles, J. L., Ramírez-Tortosa, M. C., Gómez, J. A., Huertas, J. R., \& Mataix, J. (2002). Role of vitamin E and phenolic compounds in the antioxidant capacity, measured by ESR, of virgin olive, olive and sunflower oils after frying. Food Chemistry, 76(4), 461-468.

Rosenthal, A., Pyle, D., \& Niranjan, K. (1998). Simultaneous aqueous extraction of oil and protein from soybean: mechanisms for process design. Food and Bioprocess Technology, 76(4), 224230.

Rosenthal, A., Pyle, D. L., \& Niranjan, K. (1996). Aqueous and enzymatic processes for edible oil extraction. Enzyme and Microbial Technology 19(6), 402-420.

Sánchez-Zapata, E., Fernández-López, J., \& Angel Pérez-Alvarez, J. (2012). Tiger nut (Cyperus esculentus) commercialization: Health aspects, composition, properties, and food applications. Comprehensive Reviews in Food Science and Food Safety, 11(4), 366-377.

Savoire, R., Lanoisellé, J.-L., \& Vorobiev, E. (2013). Mechanical Continuous Oil Expression from Oilseeds: A Review. Food and Bioprocess Technology, 6(1), 1-16.

Sineiro, J., Domínguez, H., Núñez, M. J., \& Lema, J. M. (1998). Optimization of the enzymatic treatment during aqueous oil extraction from sunflower seeds. Food Chemistry, 61(4), 467474.

Smith, D. D., Agrawal, Y. C., Sarkar, B. C., \& Singh, B. P. N. (1993). Enzymatic hydrolysis pretreatment for mechanical expelling of soybeans. Journal of the American Oil Chemists' Society, 70(9), 885-890.

Sorin-Stefan, B., Ionescu, M., Voicu, G., Ungureanu, N., \& Vladut, V. (2013). Calculus Elements for Mechanical Presses in Oil Industry.

Stanković, M. S. (2011). Total phenolic content, flavonoid concentration and antioxidant activity of Marrubium peregrinum L. extracts. Kragujevac Journal of Science, 33, 63-72.

Uhm, J. T., \& Yoon, W. B. (2011). Effects of high-pressure process on kinetics of leaching oil from soybean powder using hexane in batch systems. Journal of Food Science 76(6), E444-449.

Valavanidis, A., Nisiotou, C., Papageorgiou, Y., Kremli, I., Satravelas, N., Zinieris, N., \& Zygalaki, H. (2004). Comparison of the radical scavenging potential of polar and lipidic fractions of olive oil and other vegetable oils under normal conditions and after thermal treatment. Journal of Agricultural and Food Chemistry 52(8), 2358-2365.

Yeboah, S. O., Mitei, Y. C., Ngila, J. C., Wessjohann, L., \& Schmidt, J. (2012). Compositional and structural studies of the oils from two edible seeds: Tiger nut, Cyperus esculentus, and asiato, Pachira insignis, from Ghana. Food Research International, 47(2), 259-266. 
Figure and Table Captions

578

579 Figure 1: Effect of moisture content and particle size on oil recovery (mean)* from tiger nuts

580

581

582

583

584

585

586

587

588

589

590

591

592

593

594

595

596

597

598

599

600

601

602

603
$*$ Standard error $=1.51$

Figure 2: Effect of High Pressure on Oil Recovery (mean)*

*Standard error $=0.03$

Figure 3: Confocal images showing intact cell walls of control, and high pressure treated tiger nuts (A-D), and damaged cell walls of enzyme treated tiger nuts $(E) *$ white arrows indicate cells walls.

Figure 4: Absorbance values (mean)* reflecting methanol content in tiger nut tissues

Standard error $=0.14$

Table 1: Fatty Acid Composition

Table 2: Quality indices, tocopherol and total phenols in tiger nut oil

5

6

7


604 FIGURES

605

606

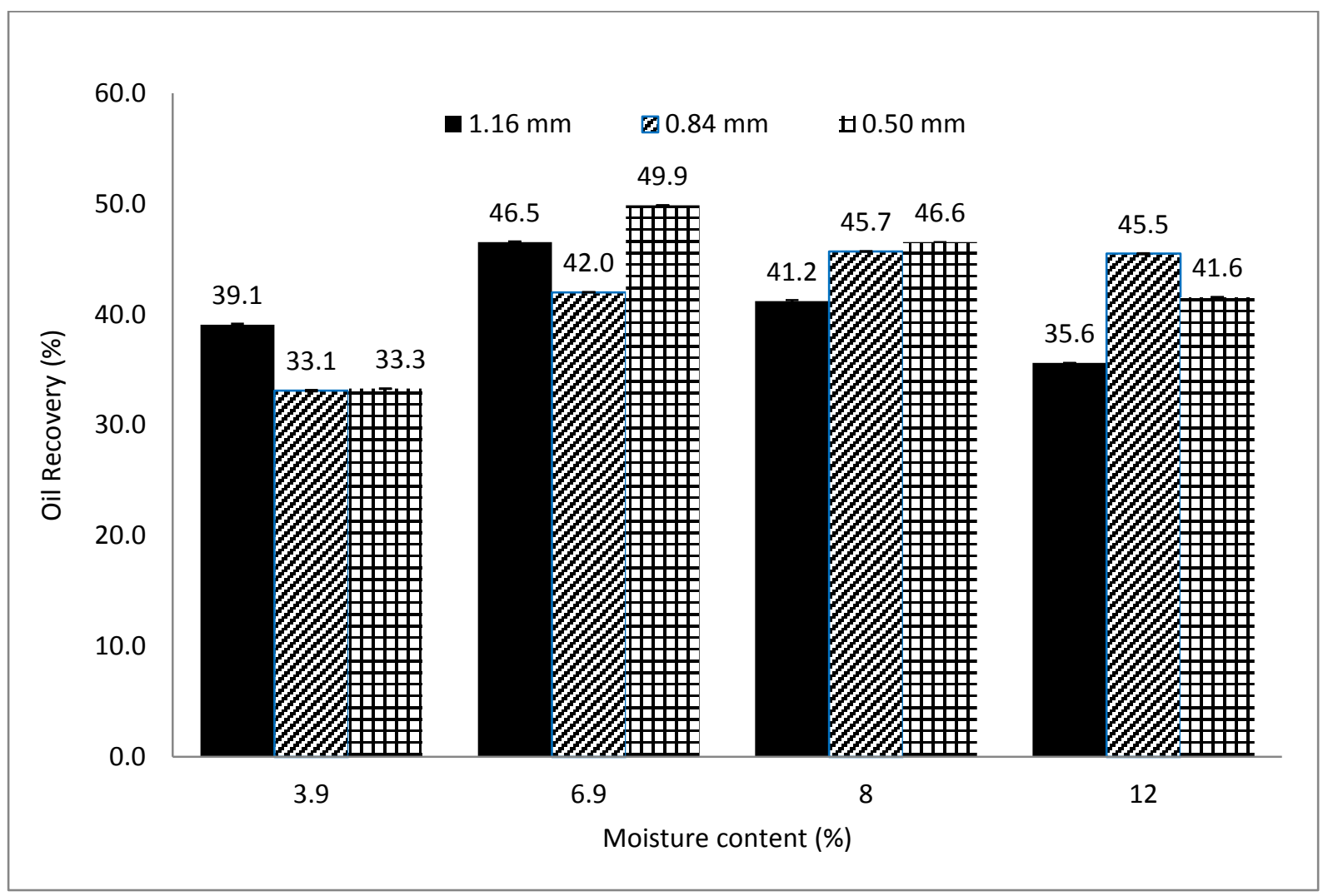

608 Figure 1

609

610

611 


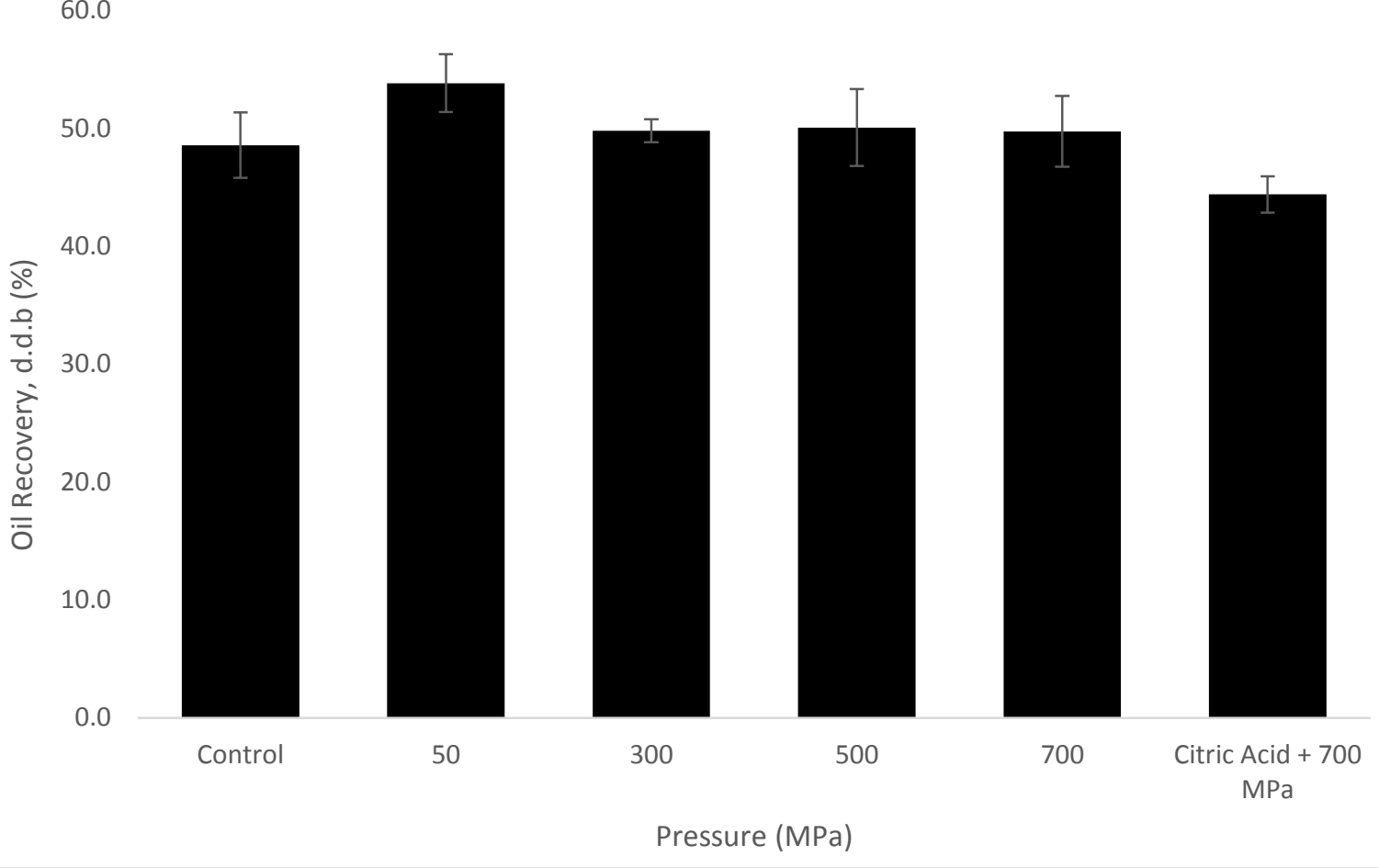

614

615

616

Figure 2

617

618

619

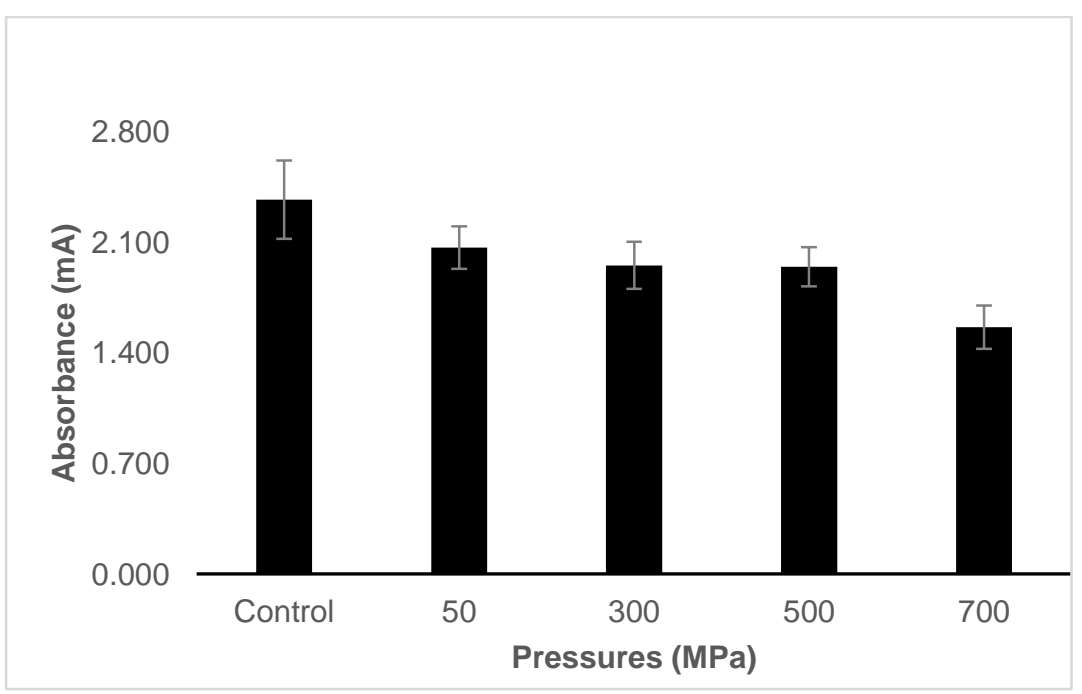

620

621

622

Figure 4 


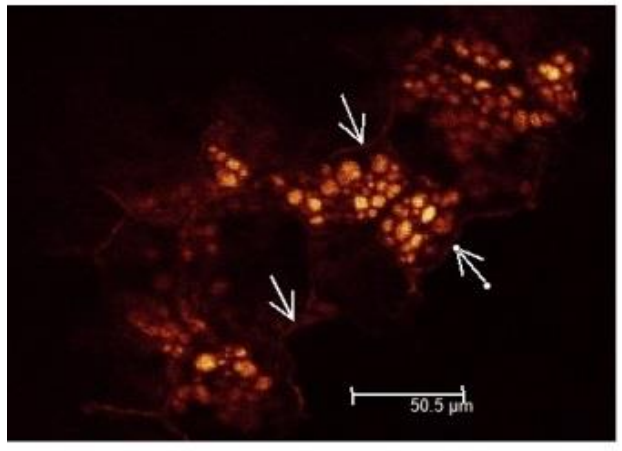

A: Control

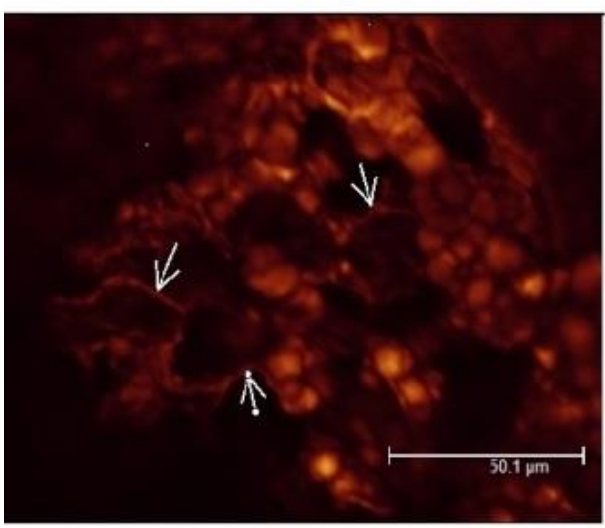

C: $\mathbf{5 0 0} \mathrm{MPa}$

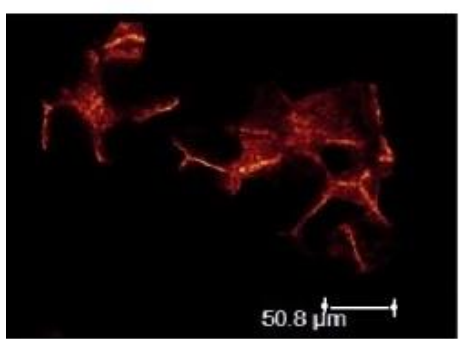

E: Enzyme treated

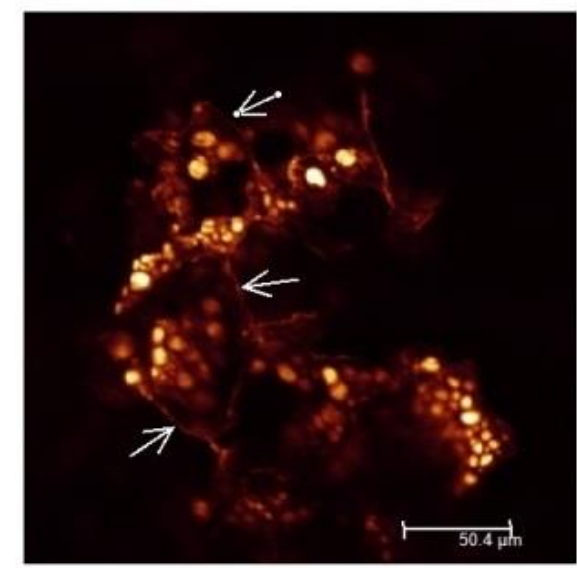

B: $300 \mathrm{MPa}$

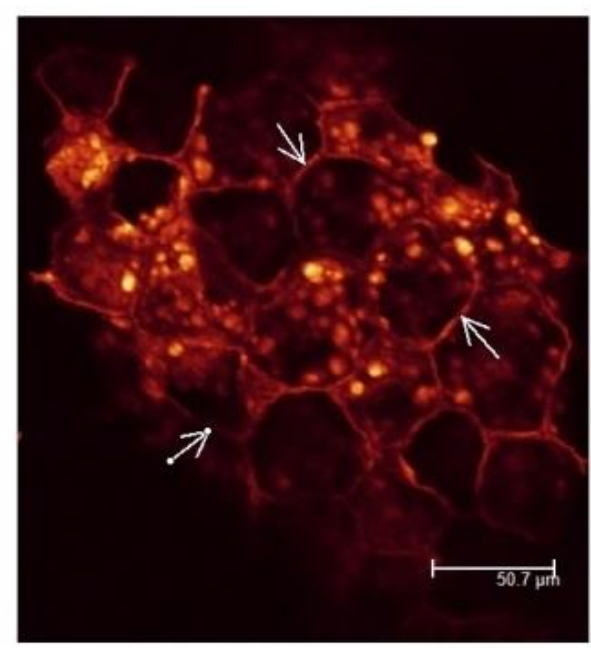

D: $700 \mathrm{MPa}$ 
631

632

633

634

635

636

637

638

\begin{tabular}{llll}
\hline $\mathrm{AV}(\mathrm{mg} \mathrm{KOH} / \mathrm{g})$ & $\mathrm{PV}(\mathrm{mEq} / \mathrm{kg})$ & $\begin{array}{l}\text { Total Phenols } \\
(\mathrm{mg} \mathrm{GAE} / \mathrm{kg} \text { oil })\end{array}$ & $\alpha$-tocopherol $(\mu \mathrm{g} / \mathrm{g})$ \\
\hline $1.2 \pm 0.00$ & $2.1 \pm 0.02$ & $17.9 \pm 0.04$ & $145.7 \pm 2.34$ \\
\hline
\end{tabular}

Table 1

\begin{tabular}{ll}
\hline Fatty Acid & Tiger nut oil \% \\
\hline C14:0 & $0.10 \pm 0.00$ \\
C16:0 & $13.5 \pm 0.00$ \\
C16:1 & $0.3 \pm 0.00$ \\
C18:0 & $6.3 \pm 0.03$ \\
C18:1 & $67.4 \pm 0.07$ \\
C18:2 & $10.7 \pm 0.05$ \\
C18:3n6 & $0.1 \pm 0.00$ \\
C20:0 & $0.7 \pm 0.01$ \\
C20:1 & $0.1 \pm 0.00$ \\
C24:0 & $0.2 \pm 0.01$ \\
Unknown & $0.4 \pm 0.02$ \\
\hline
\end{tabular}

Table 2 